\title{
* Bank Credit and Economic Development: An Empirical Analysis of Indian States
}

\author{
Rashmi Umesh Arora
}

\section{Introduction}

The economic reforms were introduced in India in July 1991. The immediate reasons for economic reforms, however, were not motivated solely by the introduction of market mechanisms. Rather, they were precipitated by the crisis led by high budget deficits; rise in external debt; sharp decline in foreign exchange reserves; and downgrading of India's credit rating. Major international developments like disintegration of U.S.S.R. also contributed in the introduction of economic reforms (see Bhagwati, 1995). Another reason usually ascribed for economic reforms in developing countries is the pressure from international financial organisations such as, IMF and World Bank. This, however, according to Pederson (2000), has not been a significant factor in case of India (1). Nevertheless, reforms introduced initially to meet the crisis, had overall long-term broad objectives of accelerating economic growth and eliminating poverty. They covered fiscal, monetary, trade and exchange rate reforms and also sectoral reforms comprising industry, agriculture and financial sector. Banks were the key targets within financial sector reforms and reforms herein aimed to improve efficiency and competitiveness of the banking system.

As in many countries, in India also banks are an important financial intermediary. The ratio of bank credit to gross domestic product was 10.3 per cent in 1970-71 and rose to 51 per cent at end March 2007. In the pre-reform period (up to 1991), the banks inculcated saving habits through branch expansion, mobilised deposits, and provided credit to agriculture and industry. The policy of government ownership of banks and directed credit, however, led to losses; inefficient credit allocation; high non-performing assets; low competition; political and administrative interference in decision-making; poor supervision; and inefficiency. Although the reforms led to increased profitability of banks, bank credit declined to the less developed states and moved in favour of the developed states.

Our paper examines the role of bank credit in the economic development of different states more so in Uttar Pradesh (UP), a large, but a less developed state of India (2). The paper departs from other studies and explores credit's role in the states with a difference. Most studies examine credit in terms of growth and output, and theoretical as well as empirical literature on credit has evolved around economic growth. This, however, does not reflect development outcomes of bank credit. Development in our study is referred in a broader sense and includes economic growth and human development. We believe that an understanding of developmental roles of credit can lead to better policy interventions. The purpose of this paper is, therefore, to have an understanding of these multiple roles of credit.

Our study argues that the development outcomes of credit vary for different groups of people, regions, and population (rural/urban). It thus relates credit to a set of, what we term as, G-GUIDE indicators where: $G$ stands for growth, $G$ for globalisation, $U$ for urbanisation, $I$ for inequality, $D$ for development and $E$ for empowerment. By 
exploring credit as the source of growth, globalisation, urbanisation, inequality, development and empowerment, it examines whether bank credit has played a role in economic growth, globalisation, urbanisation, inequality, poverty reduction, and empowerment of women. The paper within this framework examines credit to the different states of India and is organised as follows. It first looks closer at the rationale and need for G-GUIDE of credit. Thereafter, the concept is applied in Indian context and its states overall. Next, we investigate this in a less developed state, UP and examine how outcomes within this framework have differed from other states. Finally, the study based on its findings concludes. It needs to be pointed out that the objective of the study is to explore the overall applicability of the concept of G-GUIDE. The study therefore, does not deal specifically with the pre-reform or post-reform period but considers the overall developments. In addition, the relationship between G-GUIDE variables and credit could be associational rather than strictly causal in nature as for instance, bank credit as a source of urban transformation.

\section{Rationale and Need for G-GUIDE of credit}

A large literature, including early and recent literature, exists on bank credit-growth nexus and banks therein have been assigned an important role in economic growth. The literature thus emphasises that banks mobilise savings and allocate credit for production and investment. They monitor borrowers, match illiquid assets with liquid liabilities, and integrate credit and liquidity provision functions (Bossone, 2000). They, thus, boost economic growth by identifying the entrepreneurs who could introduce new goods and production processes (King \& Levine, 1993a) and facilitate long-run investment in the high return projects (Bencivenga \& Smith, 1991).

Among early literature, Adam Smith highlighted banks' role in driving economic growth and attached special significance to the role of capital in his Wealth of Nations (Bowley, 1975) (3). Dunning Macleod (1821-1902), a Scottish barrister and a political economist (Skaggs, 1999; 2003), attributed positive role to banks in promoting economic growth. He argued that by lending, banks bring underutilised resources into production, extend the market by providing credit, and promote venture capitalists through cash credit facilities (see Skaggs, 1999). Bagehot (1853) also argued that the financial system played a critical role in igniting industrialisation in England (as noted in Levine, 1997).

In the recent growth literature within which markets play a key role, finance is considered as a crucial factor of production in the long-run economic growth. This literature argued that the role of financial institutions was to identify borrowers efficiently; channel investible funds to the investment projects that yield highest return, and stimulate investment and growth (Greenwood \& Jovanovic, 1990). Financial intermediation enhances economic growth by leading savings into the productive investment projects, while allowing individuals to reduce the risks associated with their liquidity needs (Bencivenga \& Smith, 1991).

This literature further argued that the financial intermediaries accelerate savings rate by offering savings products of different maturities and yields, and allocate these resources to increase investment. They can also reduce risks across projects, firms, and 
industries by risk diversification through which they accelerate technological change and economic growth. An important role, through which financial intermediaries affect economic development, is their acquisition of information (Diamond, 1984) (4). This however, is determined by their ability to reduce information and transaction costs, which in turn influences savings, investment decisions, technological innovations and long-run economic growth (Levine, 1997). Financial intermediaries economise on the costs of acquiring and processing information about investment opportunities, and thereby improve resource allocation. As large number of firms and entrepreneurs seek funds, the selection of best firms would lead to efficient resource allocation (Greenwood \& Smith, 1997).

Similar to the theoretical literature, the empirical studies on the relationship between finance and economic growth also declared "--- a positive, first-order relationship between financial development and economic growth” (Levine, 1997, p.688). King and Levine (1993a; 1993b) and Gregorio and Guidotti (1995) among others also showed that higher levels of financial development are positively associated with faster rates of economic growth.

This literature although delineated the relationship between finance and economic growth did not take into account the development outcomes of credit and the credit or finance-development nexus remained problematic. The distinction between the two became sharper in the nineties as a broader concept of economic growth evolved which included not only growth in gross domestic product but also human development. For Stiglitz (2000) in fact, development was no longer a process of capital accumulation, but rather a process of change, and "a transformation of society, of a move from old ways of thinking, old forms of social and economic organization, to new". As given earlier, banks had also played a significant role in economic development through channeling credit in desired directions, deposit mobilisation and establishing large branch banking network. The overemphasis on finance-growth in the theoretical and empirical literature also led to an emergence of dilemma among the policy makers on whether finance is for growth or development. The prime focus on growth and efficiency led to the poor and other development issues being sidelined and credit to the poor evolved separately in the form of microfinance. Thus, microfinance was hailed as the new revolution in the development literature. However, lately a few studies have emerged which challenge the existing literature in which banks/finance are seen solely as engine of economic growth overlooking its developmental roles (De La Torre, Gozzi, \& Schmukler, 2007; Stallings \& Studart, 2006). Our paper, by exploring the multidimensional roles of credit as the source of globalisation, urbanisation, inequality, development and empowerment seeks to move beyond the narrow confines of microcredit.

\section{G-GUIDE of Credit and India}

Credit and Growth

Table 1 presents the key variables (G-GUIDE) and indicators used therein to explore multiple roles of credit. 
The annual average growth rate of the Indian economy in the post-independence period (1950-80) was 3.5 per cent. This steady slow rate of growth during the long period of three decades was mockingly termed as 'Hindu rate of growth' (5). During later decades (1980s, 1990s and 2000-01 to 2003-04), the average real growth rate, though higher, was again stuck at 5.8 per cent (6). This was termed as 'new Hindu rate of growth' (see Virmani, 2004). During 2003-04-2006-07 however, the real growth rate averaged 8.6 per cent. The turning point from 'Hindu rate of growth' (whether eighties or nineties); quality and sustainability of growth (much propelled by services sector) and its future trend, is much debated.

As pointed out earlier, banks are the most important financial institutions in India and Development Financial Institutions (DFIs) and capital market have played a negligible role. Bank credit-output ratio was 32.3 per cent in 2000-01 and rose gradually to about 52 per cent in 2006-07. In contrast, the credit by DFIs and capital market formed only 1-3 per cent. The growth of bank credit has exceeded India's growth rate in almost all the years since 1970. The annual average growth rate of three sectors, agriculture, industry and services, since seventies, covering both pre-reform (before 1991) and post-reform period (after 1991), shows that output growth has remained lower than credit growth. In the pre-reform period, credit helped in accelerating agriculture and industrial output and contributed to structural change (Bell \& Rousseau, 2001). The nationalisation of banks in 1969, directed credit policies and other regulatory policies aimed to push agricultural and industrial output. In the post-reform period, the sector pushing economic growth is the services sector. The credit to this sector as share of GDP also increased in the post-reform period though it is less than the growth in its output.

\section{Credit and Development}

Poverty reduction is considered as development indicator in the present paper (see Table 1). Reduction in income poverty as an indicator of development has been benchmarked by other agencies including United Nations (UN 2003). The World Bank also gave topmost priority to reduction in extreme poverty in its Millennium Development Goals (7). In India also, poverty reduction is an important development indicator. The poverty level in India declined from 54.9 per cent in 1973-74 to 27.5 per cent in 2004-05. The decline was both in rural and urban poverty from 56.4 per cent and 49.0 per cent in 1973-74 to 28.3 per cent and 25.7 per cent respectively in 2004-05. The density of poverty that is, the number of poor per unit of area in India was 91.8 per sq $\mathrm{km}$ in 2004-05. This, however, varies significantly from 39.4 people per sq $\mathrm{km}$ in Rajasthan to 392 per sq km in Bihar.

Many direct and indirect measures have been taken to reduce poverty in India. The early initiatives, although indirect in nature were: community development programmes; abolition of zamindari system (9); land reforms; and introduction of high yielding varieties of seeds, mainly wheat and rice in agriculture. As an indirect measure, nationalisation of the banks in 1969 also aimed to reduce poverty. Direct attack on poverty was through various schemes primarily targeted at rural areas. As against earlier focus on whole family, in the nineties many schemes aimed directly at women and children. The agency aiming at poverty reduction also changed from government departments, to increased involvement of non-governmental organisations (NGOs). 
Thus, three major shifts in methods, targets and agency in the poverty scene in India are: i) indirect to direct measures of poverty reduction; ii) family poverty to gender and child related poverty; and iii) government to NGOs or government-NGO partnership. The concept of poverty has also changed from solely income poverty to non-income poverty as well.

In the attack against poverty, the role of credit is limited to its effectiveness in dealing with income poverty only. Credit cannot reduce non-income poverty related to human development directly. The effect of credit on non-income poverty would be through its effect on increasing income, and trickle through its effect on other aspects. The impact of credit on poverty reduction would depend on a number of factors such as employment intensity of the sector using credit, distribution of income generated (within the family or in a broader sense across the community) and the nature of economic activity itself. Our study examines poverty reduction and credit by taking into account credit to small borrowers (borrowers with credit less than Rs.25,000approximately US\$625) and microfinance. Bank credit has assisted small borrowers including poor to cross the poverty barrier (Burgess \& Pande, 2003). The latest available data shows that small borrowers constituted 93.2 per cent in terms of number of bank accounts, but had 18.5 per cent of the total outstanding credit as on March 31, 2004 (RBI, 2006). Their percentage share in outstanding credit rose from 9.2 per cent in 1975 to a peak of 25.4 per cent in June 1989. It declined subsequently to its current level of 18.5 per cent. The sectoral composition of credit to small borrowers also changed in the post-reform period. The share of agriculture in credit declined from 32.1 per cent in 2001 to 29.1 per cent in 2004. Credit to industries halved during this period from 8.4 per cent to only 4.0 per cent and the only increase was in services sector. Within services, percentage share of personal loans, including loans for housing more than doubled from 20.0 per cent in 1996 to 43.3 percent in 2004. Nevertheless, the increase in housing construction and renovation activities did provide off-farm employment to the agricultural labourers (see Ruthven \& Kumar, 2002).

In recent years, microfinance is considered an antidote to poverty and a strategy for enhancing development. As in many other countries, in India also microfinance has taken the role of 'microfinance movement'. The model mostly followed in India is SelfHelp Groups (SHGs) - bank linkage programme under which NGOs form SHGs and assist in getting credit from banks. The total number of SHGs linked to banks was 1.61 million as at end March 2005 and further increased to 2.2 million as on March 31, 2006. The bank loans per SHG increased from an average of Rs.36,179 (US\$ 904) to Rs.50,915 (US\$ 1273) in 2005-06. The number of poor families benefiting through SHGs increased from 16.7 million as on March 31, 2004 to over 32.9 million as on March 31, 2006. However, outreach of SHGs in terms of total number of poor families in India was only about 10 per cent of the total number of poor in India.

The relationship between microfinance and poverty reduction may not be positive, as credit amount linked to groups' savings is very small. Its purpose as investment is, therefore, limited. Many evaluation studies report that credit provided through microfinance only enabled low-income short-term activities and temporarily met the consumption needs of the borrowers. Among many limitations of microfinance, major ones are high rates of interest charged thus excluding very poor; and limited effects on women empowerment. The high rates arise due to three types of costs 
involved in microfinance lending. These are cost of lending; cost of loan default; and transaction cost that is, cost of appraising, processing and monitoring loan. It is argued that these interest rates are still lower than those charged by moneylenders (GroenGoodwin, 2002). Not only interest rates are high, they also vary from region to region. Kamesan (2003) observed, "microfinance has had an asymmetric growth across the country (India) with diverse rates of interest being charged" (Kamesan, 2003, p.1). The operational problems relating to SHGs-bank linkage in the Indian context are delays in opening of bank accounts; large number of visits to banks to obtain credit; and impounding of savings of SHGs as collateral for loans. These operational issues, for instance, opening of bank accounts of SHGs and provision of credit could be also due to the lack of reliability of the SHG group.

\section{G-GUIDE of Credit and States}

Credit and Growth

Except in the fast growing, developed and industrial states like Maharashtra and Tamilnadu, share of almost all states of India in total bank credit has remained around 5.0-6.0 per cent during 1972-2004. Maharashtra received more than 20.0 per cent of bank credit throughout the years 1972-2004, and even surpassed 30.0 per cent in 2002. The share of Tamilnadu has remained almost constant, about 10.0 per cent. Among medium achiever states, in West Bengal despite high growth rate in post-reform period bank credit declined from 15.7 per cent in 1969 to 5.4 per cent in 2004. Overall, credit throughout this period remained highly unequal with standard deviation across the states- 6.81 in 2004, slightly lower than 7.01 in 1972.

Besides credit, banks also invest in the state government securities and bonds (10) and combined with credit they indicate total funds to the states from banks. They were also a part of the broader developmental objective of assisting state governments with their finances. Among high achiever states, Maharashtra, which came out top in bank credit, retains its position in terms of these investments. The southern states Andhra Pradesh, Karnataka, and Tamilnadu, received major share of both credit and investment. In the less developed states, while the share of banks' investments has remained high in pre-reform and post-reform period, taking both investment and credit into account, these states have received lesser funds.

Another indicator with the developmental connotation is credit-deposit ratio (C/D), now less frequently used in policy discussions. The concept was used to judge credit received by less developed regions in relation to their deposits. It indicates, "credit direction of banks and is used as a credit efficiency indicator for analysing the role of banks in promoting productive sectors and contributing to economic growth" (RBI, 2003; 2005, p.77). In 2004, this ratio showed large variations across the states, ranging from $8.2-105.3$ per cent. In the western region, C/D ratio was 72.0 per cent, within which Maharashtra was 81.8 per cent (excluding Mumbai it is 50.4 per cent). In Tamilnadu (southern region), the ratio was 93.1 per cent (excluding Chennai it falls to 68.9 per cent).

\section{Credit and Development}

This paper had examined earlier credit as a source of development in all-India 
context and indicator of development was reduction in poverty. Therein, the poverty reduction strategies and role of credit were briefly outlined. Although poverty at the overall national level has reduced, this varies across states. To examine relationship between credit and development, we consider credit to the small borrowers and microfinance. Figure 1 shows credit to small borrowers and poverty in different states. It shows existence of low number of credit accounts with high average credit amount per account to small borrowers in prosperous states, Punjab and Haryana. Contrasting this was high number of credit accounts, with low credit amounts of small borrowers in states with high incidence of poverty. Figure 2 highlights disparity in credit and poverty concentration across regions. It shows that in contrast with its poverty level, the southern region (includes Andhra Pradesh, Karnataka, Kerala, Tamilnadu, Lakshdweep and Pondicherry) received most credit. The contrasts in the magnitude of credit and poverty are marked in central (includes Madhya Pradesh, UP, Uttaranchal and Chattisgarh) and north-eastern region (Arunachal Pradesh, Assam, Manipur, Meghalaya, Mizoram, Nagaland and Tripura).

As in the case of bank credit, microfinance also concentrates in the southern region with 63.0 per cent of SHGs and 79.0 per cent of SHG credit in 2004, covering only 15.4 per cent of the poor. Andhra Pradesh and Tamilnadu were leading states within this group. In contrast, Assam, Bihar, Madhya Pradesh and UP account for much smaller share of SHGs and SHG credit. The SHGs are, therefore, more active in states where poverty is low, and less active in other states (Basu \& Srivastava, 2005; Dasgupta, 2005). The states, according to their level of SHG development can be grouped as SHGleading states and SHG-lagging states. The criteria for classifying states into these groups are SHG credit per poor person; coverage of poor families; and number of SHGs (Dasgupta, 2005). The SHG-leading states (Andhra Pradesh, Karnataka, Kerala and Tamilnadu) have high SHG credit per poor; widespread coverage of poor; and large number of SHGs. In SHG-lagging states (high poverty states- Bihar, Madhya Pradesh and UP), coverage of families; credit amount per SHG; and number of SHGs are all low. Thus, SHG-bank linkage programme suffers from same trend that afflicted bank credit: they are concentrated in states which are more developed, and have less poverty. Nevertheless, though credit given by SHGs in the less developed states is low, they have assisted in improving banking habits of the poor, especially women (Varman, 2005).

Recent data again showed that substantial increase in SHGs in all states was to the SHG-rich region, notably southern states like, Andhra Pradesh, Karnataka and Tamilnadu and the increase ranged from 11-20 per cent. The total share of these three states was 44 per cent in additional SHGs in 2005. Conversely, share of the less developed states- Bihar, Orissa and UP was 18 per cent and disproportionate to the extent of their poverty.

\section{Credit and Inequality}

Could credit or finance generate inequality? The credit constraints could lead to inequalities in the rural-urban credit, which could further foster inequality in incomes. Credit inequality can be measured by: i) proportion of rural and urban credit to total state credit; ii) change in rural credit between 1996 and 2004; and iii) proportion of semi-urban to urban credit. The semi-urban areas are towns with population of 10,000 and above but less than 1 million (11). These towns have a unique identity as they bear 
the characteristics of both rural and urban areas; are not fully developed; and could be focal points of future growth. Although the causal factors of inequality in credit across the rural and urban areas could be many including different level and scale of economic activities in the two areas, our analysis shows that credit inequality actually increased in the developed as well as less developed states. It decreased in some states such as, Himachal Pradesh in northern and Arunachal Pradesh in the north-eastern region. The states with high (more than 10 percent) credit inequality in 2004 over 1996 were Haryana, Bihar and Rajasthan; states with medium credit inequality (5-10 percent)Gujarat, Punjab, Madhya Pradesh and UP and lastly, states with low credit inequality (less than 5 percent) are West Bengal, Maharashtra, Kerala and Tamilnadu. Even in agriculturally prosperous states such as Punjab, Haryana and UP, urban credit was still between 74-78 per cent of total (Table 2). Overall, per person credit was high among all states in the urban areas.

It is possible that in the nineties shift in credit was towards the semi-urban areas, which exist in the periphery of urban areas. Such towns formed 66.5 per cent of total number of towns in all India and their share in country's total urban population was 28.8 per cent. Our study finds that as in rural credit, semi-urban credit also declined during the period 1996 to 2004. Thus, while credit increased in urban and metropolitan areas, it decreased in rural and semi-urban areas. To examine the reasons behind the shift to urban credit in various states, it is necessary to explore whether any relationship exists between urban credit and per capita income of the state. The correlation coefficient between the two at +0.64 was positive and strong indicating that the higher the per capita income, the higher is the share of urban credit. A strongly positive relation $(+0.77)$ also exists between the extent of urbanisation in the state and urban credit. Thus, the states such as Maharashtra, having a high share of urban population also had a high share of urban credit. Urbanisation in Maharashtra was the second highest in the country at 42.4 per cent. The credit to the urban areas in the state was 96.0 per cent.

Credit inequality exists not only across rural and urban population, but also within population groups, for instance, small and large borrowers. In some states like Madhya Pradesh, West Bengal and Maharashtra, small borrowers in both rural and urban areas received almost same level of credit and states' ranking remained same. Overall, small borrowers in 2004 accounted for 93.2 per cent of total number of accounts; their share in total amount borrowed was only 18.5 per cent. In other words, about 82 per cent of credit amount went to large borrowers who have only 6.8 per cent of credit accounts.

\section{Credit and Urban Transformation}

The studies on bank credit have not explored role of credit as forerunner of urbanisation. A shift of credit from rural to urban areas can highlight rural-urban inequality, but can also lead to urban transformation and urbanisation. Our study treats the two terms as distinct, as effect of credit would first lead to change and transformation in the urban areas, gradually leading to increased urbanisation via urban growth and migration from rural to urban areas. Therefore, credit in this sense assists in fostering transformation or change and urbanisation, by shifting the loci of activities from agriculture to manufacturing and services. 
In recent years, urbanisation is regarded as a significant factor in economic growth. The percentage of urban population in total population in India at 27.8 per cent in 2001 is, however, much lower than many countries including Latin America, and even many in Africa. In many states such as Gujarat, Kerala, Tamilnadu, Rajasthan, and Haryana increase in credit to urban areas has occurred during 1996-2004. This increase was lower in less developed states like, UP and Bihar. Despite the critical role of infrastructure, increased credit to the urban areas in India in recent years has been for personal loans like housing, which has made little contribution to the immediate and rapid growth of urbanised areas. Even the effect of increased housing loans for construction and renovation of houses on urbanisation, in recent years, has been limited largely due to the low impact on the rural-urban migration of workers (Ruthven \& Kumar, 2002).

\section{Summary}

To recapitulate, our objective in this paper was to explore credit not just in terms of one or two variables, like growth and development, but also to capture multiple dimensions of credit, such as source of rural-urban inequality; inequality across small and large borrowers; urban transformation; empowerment and globalisation. In this section, we examined credit as source of growth and development in overall India context and further credit as the source of growth, development, inequality and urban transformation across states. This multidimensional approach to credit looked at its trends and pattern in rural/urban areas, small/large borrowers and different sectors. To summarise, at the national and states' level, credit has influenced output growth, but its direction has been more towards large borrowers, developed states, and urban areas. It has had a limited effect on urban transformation. Next we apply the concept of GGUIDE of credit in case of UP.

\section{G-GUIDE of Credit and UP}

Credit and Growth

An intense debate exists in India on the quality, sustainability and factors propelling economic growth of the country overall. This debate appears inappropriate in the context of UP, as concern here is more on the lack of growth, and factors contributing to low or negative growth in the state. During the period 1950-51 to 197071 , the annual average growth rate of UP was 2.2 per cent which rose to 5.0 per cent in the decade $1980-81$ to $1990-91$. In the post-reform period that is, after 1991 while the country's growth rate has been much higher, the growth rate of the state has lagged considerably behind particularly, since 1997-98. During the year 2002-03, the state's growth rate declined by 1.5 per cent, largely due to a decline in the agricultural output. The reasons, which explain poor performance of the state, are tapering of the green revolution effect in the nineties, decline in investment, low human development, and political instability in the state.

The bank credit in UP in 1972 was 4.9 percent of total credit. In 2004, this was down to 4.5 per cent, that is, its share reduced even below its level in 1972. Nevertheless, banks still remained major source of credit to the state, and other sources like capital market and DFIs formed only small proportion of total credit. Per capita credit in UP in 2004 was the lowest after Bihar. It was only 8.9 per cent of 
Maharashtra's per capita credit and only 3.0 per cent of an emerging state like Delhi.

Has credit then worked as the source of growth in UP? As shown above, the annual average growth rate of UP was 5.0 per cent during the period 1980-90. Agricultural output during this decade grew by 3.2 per cent. Within agriculture, the food grains output increased from 2.3 per cent in 1961-62 to 1968-69, to 4.2 per cent in the period 1971-72 to 1983-84. The production of wheat and rice increased to 7.5 per cent and 5.2 percent in the latter period. The banks under directed credit lending system had also shifted focus from industrial to agricultural credit. Thus, agricultural credit in UP was 14.9 per cent in 1972, increased to 26.3 per cent in 1981, but declined steadily since then.

A sort of sectoral redistribution of credit took place in the state as credit to agriculture declined as also the industrial credit which fell from 60 per cent in 1972 to nearly 30 per cent in 2004. On the other hand, services credit continued to rise throughout, accompanied with deprivation in credit to other sectors (12). The share of services credit was 42.4 per cent in 1993-2004, higher by 5.4 percent from its average share in 1983-92. Industrial credit declined by 3.2 percent during the similar period. In 1972, around 60.0 per cent of credit in the state was to industries. As at end March 2004, this declined to 26.9 per cent. The share of agriculture too declined to 20.8 per cent in 1993-2004, a decline of 1.7 per cent over 1983-92.

\section{Credit and Development}

Our study examined credit and development earlier in the all-India context and across states. It was also pointed out that the SHGs are mostly concentrated in the southern states, and share of northern states is very low. The total number of SHGs in India at the end of March 2005 was 1,618,456 of which in UP were 1,19,648 that is, about 7.4 per cent of the total. This is inadequate considering that among all the states of India UP is the most heavily populated state with 166 million of the country's total population of 1029 million. Also, the percentage of population below poverty line, although lower than that of Bihar and Orissa, is still substantially high at 32.8 percent in 2004-05. In most of the state's 70 districts, SHGs constituted less than 1 percent of the total SHGs in state. They were also concentrated in certain districts as six districts each had more than 3 per cent of the total number of SHGs in 2005, and their share in credit was 25 per cent. The percentage share of SHGs in the poorest region of the state, Bundelkhand, was only 7.7 per cent compared with 44.5 percent in the eastern region, and 30.1 per cent in the western region. This was despite the fact that poverty level in the Bundelkhand region was highest within the state. Thus because of its inadequate outreach, the role of SHGs in capital accumulation and poverty reduction is limited in UP.

Among the reasons for lower number of SHGs in the state are lesser NGOs and high transaction costs in the formation of SHGs. As NGOs form SHGs, existence of fewer NGOs in UP compared to other states explains less SHGs. In addition, the transaction costs involved in formation of such groups is high largely due to lower awareness of SHGs (Shankar, 2006).

A few district level studies available on the impact of SHGs on poverty 
reduction have noted positive impact on incomes and reduction in approach to moneylenders for consumption credit. The major problems of SHGs as observed by these studies was the lack of literacy among the members, failure to maintain proper accounts, lack of training, marketing and credit facilities. Thus SHGs can influence poverty reduction in UP, but their limited outreach and coverage of the poor, and the low quality of SHGs largely prevents achievement of this objective.

Bank credit in small quantities to small borrowers also assists in starting new enterprises, and helps them escape low investment-low income trap. In a state like UP, with high poverty levels, this has different implication from a state such as, Maharashtra. Credit per account to small borrowers in state's rural areas was Rs.635 (approximately US\$16) ranking ninth among fourteen major states. As in case of large borrowers, small borrowers in the services sector received more than 50 per cent of credit. The credit to small borrowers in agricultural sector in the nineties has not shown any increase from their earlier levels.

\section{Credit and Inequality}

Our paper uses disparity in credit between rural and urban areas as proxy indicator for credit inequality. In 1972, about three years after banks' nationalisation, credit to non-rural areas of UP was 92 per cent and rural areas only 8 per cent. Despite 33 years of massive branch banking and increased focus on agriculture, credit to the rural areas was still only 26 per cent in 2004. The marked inequality in access to credit has particularly, taken place in nineties. On an average, rural credit during 1990-2004 was 30.1 percent, and non-rural credit was 69.9 per cent. Since these are averages, they do not reveal the real extent of decline in credit since 1990. The yearly data on credit shows that the share of rural credit which was 37 per cent in 1990, declined gradually to 26.8 per cent in 2004. The focus of banks in the nineties shifted to non-rural areas, and increased credit was to services and retail lending.

The rural and urban areas are linked through demand for each other's output and employment. Increase in credit inequality could lead to negative outcomes such as, decline in agriculture output due to inadequate usage of inputs; closure of rural industries; increase in rural poverty; increased recourse to debt from informal sources; increase in landless labourers; and forced migration of workers from rural areas. The other social consequences of increase in credit inequality could be increased impoverishment and other negative social consequences. The decline in credit to the rural areas has taken place more in rural manufacturing than in the agricultural sector. This was more prominent in capital-intensive non-agro industries such as chemicals, cement and basic metals. The credit to agro-based, labour-intensive industries such as food processing, leather products, textiles, paper and paper products also declined from 11.9 per cent of the rural credit to the state in 1990 to 6.1 per cent in 2004. The similar drop in non-agro capital-intensive industries was from 19.9 per cent to 8.4 per cent. The shift from the rural to the urban sector in credit does not augur well for the state's rural sector as the rural non-farm sector is recognised as an important channel for development and reduction of poverty. 


\section{Credit and Urban Transformation}

Has the increased credit to the urban areas, as seen above, assisted in increasing urbanisation and economic growth? Credit became more urbanised and the differences in urban credit have narrowed across all regions of UP. Within rural areas, credit in the western region was highest in 1972, which declined in the nineties and non-rural and non-agricultural activities took up major share of credit. The increased credit to nonrural areas in the western region was in manufacturing and services. The increase since 1972 is however, mainly due to the high share of credit to new districts like Gautam Budh Nagar. This district, created in 1997, includes the industrial areas of NOIDA and Greater NOIDA and is adjacent to Delhi and hub of industrial and software technology activities. Credit, however, failed to push the level of urbanisation, as urban population in UP at 20.8 per cent in 2001 increased only by a mere 1 per cent from 19.8 per cent in 1991. However, it needs to be pointed out that urbanisation is a consequence of number of factors and credit may not necessarily lead to urban transformation. The lower urbanisation in UP is due to high rural to rural migration; migration to other high income and developed states such as, Maharashtra and Punjab; high inter-regional disparities and low economic growth.

\section{Credit and Empowerment}

So far we examined credit not only as source of growth, regional inequality and urban transformation, but also as a source of development wherein poverty reduction was the indicator of development. Bank credit and microfinance function not only as the tool of poverty alleviation but also as tool of empowerment. Access to credit enables women to start their own enterprises and escape poverty. Our study examined poverty alleviation earlier, it is, therefore, logical now to look at the other objective of credit that is, credit as the source of empowerment. Empowerment of women can have growth as well as development effect. The empowerment of women through education, better health and increased participation in workforce contributes to economic growth. The effect of empowerment on development through the mothers' education, leading to better nutrition and health of children, choice of family size, reduced birth rates and demographic change, is also enormous.

The hype of women empowerment in recent years even led the Government of UP include a separate chapter on women empowerment in its Tenth Five Year Plan document (Government of UP, 2002). It spells out the need for empowerment of women in the state and the various areas aimed at are improvement in female education; health and nutrition; economic empowerment of women through improved credit; social and political empowerment through increased participation of women in politics; and improved social security and protection. Empowerment, however, takes place only through social transformation through change in deep-rooted attitudes beginning at the family level. The role of the state is to facilitate that change through ensuring legal rights, increasing awareness of those rights and providing basic social services to women. Microfinance is used as one such facilitating tool to assist women in their empowerment.

The evidence on the impact of credit including microfinance on women's empowerment in UP is sparse. Compared to the southern states, where SHGs are mostly 
comprised of women, in UP mixed groups of men and women, or men only groups with a few women groups are found (Basu \& Srivastava, 2005). Mishra, Verma and Singh (2001) also observed the overwhelming membership of men in SHGs in UP. In a study of empowerment among women in eastern UP, Pandey and Mishra (2004) found that the empowerment of women is extremely low and that access to ownership of assets, property, credit and even education, has not helped in women's empowerment. They found that participation in decision-making played more significant role in women empowerment.

Not much information is available on bank credit to women in UP. The data on credit, according to gender, available only for small borrowers at all India level shows that 85 per cent of the bank credit goes to men and women receive only 15 per cent. The credit to women in the rural and non-rural areas is not very different from each other.

The share of rural and urban female borrowers in credit accounts was 17.2 per cent and 19.1 per cent respectively. In credit amount also, share of the rural borrowers at 14.1 per cent was almost same as that in urban areas at 15.3 per cent. Only in the metropolitan areas, the percentage share of women in terms of credit accounts and credit amount is slightly higher compared to that for women in other areas. In analysing bank credit to women, it needs to be pointed that in India, the borrower needs to provide evidence of assets or a guarantee by employee as collateral. As the assets are mostly in the name of male members of the family due to the patriarchal nature of the Indian society, women are often deprived of access to assets and credit. In addition, guarantees by other employees are difficult to secure due to low participation of women in the paid workforce.

\section{Credit and Globalisation in G-GUIDE}

Could bank credit serve as a source of globalisation or move towards global integration? A number of studies have debated the benefits of globalisation to the developing countries and its effect on inequality and poverty. At the sub-national or states' level, the effect of globalisation would vary depending on their level of development. The more developed states, due to their better infrastructure and availability of skilled workforce, would be able to obtain more benefits of globalisation compared to the less developed states. Even within developed states, the rich farmers and large industries will benefit, compared to the small farmers, small artisans and small-scale industry. The less developed states, at the outset, would have to improve their infrastructure to overcome their inadequate infrastructure facilities and upgrade less skilled or unskilled workforce. The importance of infrastructure and its vital role in globalisation and economic development including poverty alleviation has been observed by various studies (Yoshino \& Nakahigashi, 2000). The present study, thus, looks into the credit to infrastructure to examine bank credit as a source of globalisation. Others indicators of globalisation could be credit for foreign trade and overseas investment and acquisitions etc., however, we believe that availability of good infrastructure is the crucial enabling factor.

Time series data on credit for infrastructure (covers credit to public and private sector), including roads, power, and telecommunications, although available at national level, is lacking at state level. At all-India level, bank credit to infrastructure increased 
from 2.0 per cent in 1998 to 15 per cent in 2005. The increase is mainly due to the greater participation of the private sector in the creation and maintenance of infrastructure following the model of public-private partnership in India. In the absence of data on infrastructure credit for states, we considered availability of power to the industrial consumers, as increased and improved power supply would lead to increased output. In addition, lack of adequate power supply would be a major factor in industries move to other states with better power availability. The number of industrial consumers in UP declined from 4.0 per cent in 1990-91 to 1.5 per cent in 2005, an evidence of declining industrial output and also poor availability of power. Power sold to industrial consumers declined during this period from 30 per cent to 18 per cent (UPERC). Regarding the poor availability of power in the state, the regulatory authority - Uttar Pradesh Electricity Regulation Commission in its evaluation noted that despite reforms in the power sector the performance is far below expectations, and "even after four years of reform, large parts of the State still spend most hours of the day without electricity -----” (UPERC, 2003, p.6).

\section{Summary}

This section showed that bank credit has served as the source of growth and has assisted in increasing total output, but in the nineties, the shift has been to the services sector. As in other states, the effect on urban transformation is limited in UP as more credit has gone to the services and there has been little increase in rural-urban migration. Credit inequality increased in the state as the gap between rural and urban borrowers, and small and large borrowers widened in the post-reform period. Credit has played a limited role as the source of development as SHG-Bank linkage is inadequate considering the state's size and extent of poverty. The effect on empowerment, although positive as shown by few case studies, is also very limited due to inadequate spread of SHGs in the state. Our study also found that banks are lending more to men than to women. This finding, however, should be treated cautiously as lower credit to women could be due to their poor access to collateral assets or a lack of guarantor required in seeking bank loans.

\section{Conclusion}

In this paper, we examined the role of bank credit in economic development in India at three levels- national, states and especially UP. UP was chosen among all the states as it large, less developed and bank credit has declined to the state since the economic reforms. As given earlier, an objective of the paper was to present an overall picture of credit and not strictly in terms of pre-reform and post-reform period. The paper examined bank credit to the states with a difference. As against the narrow focus of the existing literature, the present study believes that credit outcomes vary for different groups of people, regions and population (rural/urban). Our paper, therefore, took into account the spread of credit to various regions, districts, occupations, rural and non-rural areas, and even a gendered distribution of credit. This multi-purpose and multi-dimensional picture of credit revealed that bank credit could be a source of growth $(\mathrm{G})$; globalisation $(\mathrm{G})$; urbanisation (U); generate inequalities (I) between rural and urban areas and small and large borrowers; a source of development (D); and could lead to the empowerment (E) of women. The study termed these multiple roles as the GGUIDE of credit. Our study showed that an exclusive focus on the growth effect of 
bank credit in the theoretical as well as empirical literature understates its real impact in the less developed states such as, UP. This study, therefore, urged to eschew the narrow focus on growth and consider a broader role of credit, which is growth oriented as well as developmental in nature.

Credit, within the G-GUIDE framework, generated growth in UP and helped in poverty reduction. It, however, perpetrated rural-urban inequality and widened the gap between the small and large borrowers. This credit inequality in the states led to an increase in the share of the informal or non-institutional agencies. Credit to small borrowers was lower in the high poverty states, and the reverse in the low poverty states. The empowerment of women through credit remained a distant goal. The limited data available on the gender distribution of bank credit showed that more than 80 per cent of the credit was to men, and women received less than 20 per cent. Another channel through which the economic empowerment of women can take place is through microcredit by the self-help groups (SHGs). Our study found that not only is bank credit unable to reach women, but even microcredit is paltry in UP due to the inadequacy in the outreach of SHGs. The low presence of SHGs in the states with high rural and urban poverty showed that credit is not assisting in the development of these states.

The G-GUIDE analysis in our study showed that despite the banking reforms (wherein focus was on efficiency and profitability of banks), banks' role in development did not end as they continued to influence the development outcomes. By examining various dimensions of credit, our study highlights that credit is not just an act of lending, but could lead to a whole range of other changes not related necessarily to income. Thus, we show that a broader perspective of credit as against a narrow one focused solely on growth, does portray the different roles played by bank credit. Understanding and appreciating the broader role played by bank credit in economic development has particular implications for less developed states, where the availability of credit has declined in the post-reform period.

Although in the current literature microfinance is associated with development, credit by the banks also implicitly performs a similar role. The concept of G-GUIDE in this study also extends the widely perceived finance-development nexus from microfinance to a much broader perspective. This view is supported by some recent studies which have cautioned against taking a narrow view of credit solely in terms of economic growth overlooking its developmental roles. The study does not suggest that bank credit is less relevant for growth; nor is its allocative and efficiency functions challenged. The study certainly highlights the other developmental roles of credit, which remain implicit and have not been approached in the earlier research.

The policy implication is: for credit to assist in multiple roles, it should increase. In discussing the multiple dimensions of credit and its potential in achieving higher growth and development, the present study did not consider the issues of profitability of banks. It can be examined further, how the G-GUIDE of credit as highlighted by the present study and the banks' own compulsions and requirements to achieve profits and yet maximise these outcomes can be integrated. In addition, the relationship between GGUIDE variables and credit as shown in the present paper could be associational rather than causal. More work is required in unpacking the specific factors underlying such relationships. 
1. Haggard and Kaufman (1992) point out that though international factors have been ascribed as one of the reasons for economic reforms in countries, they doubt whether this can be assigned as a major reason. They argue that the reforms were more likely to take place if favourable conditions of political support and private interests of business exist. According to Haggard and Kaufman (1992), though the reforms commonly are attributed to the ideas of senior officials and economists representing the international organisations, this is however, a narrow view of the situation, as a major reason lay within the domestic economy itself.

2. This study notes that while the secondary data on bank credit is comprehensive, according to economic activity and spatially, it lacks a human perspective. It lacks coverage of the human population, particularly the disadvantaged groups such as lower castes (considering their predominance in UP), women, and the disabled population of the state.

3. The word 'classical' refers to the economic thought of the period from mid-eighteenth century to the mid-nineteenth century.

4. Information can be explained as factual knowledge and it can be exchanged among individuals (Lapavitsas, 2003) .

5. The term has been popularly associated with Raj Krishna, a noted Indian economist, though it was actually used by B.P.R.Vithal, a noted economist and administrator (Virmani 2004). It could refer to the contentedness and belief in fate associated with Hinduism. The term also contrasts, though cautiously, the slow growth rate of the Indian economy with the high growth rate achieved by East Asian countries during the similar period.

6. The East Asian financial crisis occurred in 1997. During the year 1997-98, the annual real growth rate of India was lower at 4.8 per cent and in 1998-99 rose to 6.5 per cent. The lower growth in 1997-98 was a consequence of negative growth in agriculture rather than a consequence of crisis. The immediate impact of the East Asian crisis on India was limited due to the capital controls such as restrictions on short-term debt and other controls. The overall longterm impacts on India were positive in nature and crucial. These were: i) the crisis underscored the importance of effective bank supervision and regulatory policies; ii) highlighted the importance of transparency; and iii) led to the fine-tuning and smoothing of macro policies through the adoption of multiple indicator approach which included interest rates, credit and other indicators such as output, exchange rate, and inflation.

7. The Millennium Development Goals were set at the United Nations Millennium Summit held in September 2000 when 189 countries took oath to fight against poverty, hunger, illiteracy, gender inequality, diseases and environmental degradation. The first goal is to eradicate extreme poverty and hunger and two targets have been set to achieve this goal. Target 1 is to halve between 1990 and 2015, the proportion of people whose income is less than $\$ 1$ a day. Target 2 is to halve during the same period, the proportion of people who suffer from hunger measured by, i) prevalence of underweight in children under 5 years of age; and ii) proportion of population consuming less than minimum level of dietary energy consumption as percentage of total population. The rationale for considering underweight children under 5 years as the proportion of population suffering from hunger is that chronic hunger is reflected early in life and underweight children subsequently grow up to be unhealthy and sick. The measure of extreme poverty is $\$ 1$ a day (UN, 2003).

8. The $55^{\text {th }}$ round of NSSO survey was the large sample survey conducted after five years by National Sample Survey Organisation. The debate arose essentially due to differences in the estimates of poverty between NSSO and National Accounts, and the change in the survey methodology from the usual recall period of 7 days used in earlier household surveys to 30 days recall period used in the $55^{\text {th }}$ round. The $55^{\text {th }}$ round of survey was the first full sample survey after the introduction of reforms. The increased interest was therefore, due to: need to judge the effectiveness of economic reforms in terms of reduction in poverty; interest not only within the 
country but also internationally, as this coincided with the increased emphasis on the reduction of poverty by the multilateral organisations; and spread of globalisation.

9. It refers to the feudal landowners called zamindars who paid government a fixed revenue during the British rule.

10. The banks not only provide credit but also invest in the state government securities (consisting of securities floated by state governments, bonds of state level bodies guaranteed by the state governments, share capital of Regional Rural Banks and debentures of cooperative institutions). As part of the statutory liquidity ratio requirements, banks are required to invest 25 per cent of their net demand and time liabilities in central and state government securities and other approved securities. This ratio was reduced from 38.5 per cent in February 1992 to the statutory minimum of 25 per cent in October 1997. The banks are usually holding securities much over and above the required level and this moved up to as much as 42.7 per cent of the net demand and time liabilities in April 2004. The factors that influence banks' decisions to invest in state government securities, include health of the state government finances; transparency of state budgets; policy announcements of the state governments; and credibility of their policy actions. Moral suasion from the central bank also plays a part in banks' investing in the state securities and bonds of less developed states.

11. In the Census of the Government of India, the towns are divided into six groups based on the population. These groups are Class I towns with population of 1 million and above, Class II with population of 50,000-99,999; Class III as towns with population of 20,000-49,999; Class IV with population of 10,000-19,999; Class V with population of 5000-9999; and towns with population of less than 5000 are classified as Class VI towns (Government of India, 2004). From the perspective of banks, the semi-urban areas are defined as those with population of more than 10,000 to less than 1 million and urban areas as those with population of 1 million and above (RBI, 2004).

12. Throughout the study, construction is included as part of the services sector in the data series on state output and credit. The issue of classification of construction as industrial or services sector activity has been much discussed in the Indian literature due to its implications for assessment of structural shifts in the economy. While in the Indian national accounts construction is included as industrial activity, the Reserve Bank includes it under services sector. In other countries, also there is no uniform practice (RBI, 2003). The dilemma was first posed by Clark (1940), who pointed out that construction should be a part of the services sector, as besides new buildings, it also involves repairs and maintenance.

\section{References}

Ahluwalia, M. (2002). State Level Performance Under Economic Reforms in India. In A. O. Krueger (Ed.), Economic Policy Reforms in the Indian Economy (pp. 91-125). New Delhi: Oxford University Press.

Basu, P., \& Srivastava, P. (2005). Exploring Possibilities, Microfinance and Rural Credit: Access for Poor in India. Economic \& Political Weekly(April 23), 1747-1755.

Beck, T., \& Levine, R. (2004). Legal Institutions and Financial Development (NBER Working Papers Series No. Working Paper 10417). Cambridge, MA: National Bureau of Economic Research.

Bell, C., \& Rousseau, P. (2001). Post-independence India: a case of finance-led industrialization? Journal of Development Economics, 65, 153-175.

Bencivenga, V., \& Smith, B. D. (1991). Financial intermediation and economic growth. Review of economic studies, 58(194), 195-209.

Bhagwati, J. (1995). India in Transition : Freeing the Economy. Oxford: Clarendon Press.

Bossone, B. (2000). What makes Banks Special? A study on banking, finance and economic development (Working Paper No. 2408). Washington: World Bank.

Bowley, M. (1975). Some Aspects of the Treatment of Capital in The Wealth of Nations. In A. S. Skinner \& T. Wilson (Eds.), Essays on Adam Smith (pp. 361-376). Oxford: Clarendon Press.

Burgess, R., \& Pande, R. (2003). Do Rural Banks Matter? Evidence from Indian Social Banking (Working Paper). London: London School of Economics.

Clark, C. (1940). The Conditions of Economic Progress. London: Macmillan.

Dasgupta, R. (2005). Microfinance in India, Empirical Evidence, Alternative Models and Policy 
Imperatives. Economic and Political Weekly(March 19), 1229-1236.

De La Torre, A., Gozzi, J. C., \& Schmukler, S. L. (2007). Financial Development: Maturing and Emerging Policy Issues. The World Bank Research Observer, 22(1), 67-102.

Deaton, A., \& Kozel, V. (Eds.). (2005). The Great Indian Poverty Debate. New Delhi: Macmillan India Ltd.

Diamond, D. (1984). Financial intermediation and delegated monitoring. Review of Economic Studies, 51(166), 393-414.

Fase, M., \& Abma, R. (2003). Financial environment and economic growth in selected Asian countries. Journal of Asian Economics, 14(1), 11-21.

Government of India. (2004). Statistical Abstract India 2004. New Delhi: Central Statistical Organisation, Ministry of Statistics and Programme Implementation, Government of India.

Greenwood, J., \& Jovanovic, B. (1990). Financial development, growth, and the distribution of income. Journal of Political Economy, 98(5), 1076-1108.

Greenwood, J., \& Smith, B. D. (1997). Financial markets in development, and the development of financial markets. Journal of Economic Dynamics and Control, 21(1), 145-181.

Gregorio, J. D., \& Guidotti, P. E. (1995). Financial Development and Economic Growth. World Development, 23(3), 433-448.

Groen-Goodwin, R. (2002). Making Sense of Microcredit Interest Rates (CGAP Donor Brief No. 6). Washington DC: CGAP.

Haggard, S., \& Kaufman, R. R. (1992). Introduction: Institutions and Economic Adjustment. In S. Haggard \& R. R. Kaufman (Eds.), The Politics of Economic Adjustment (pp. 3-37). Princeton, New Jersey: Princeton University Press.

Kamesan, V. (2003). Micro Finance. Mumbai: Reserve Bank of India.

King, R. G., \& Levine, R. (1993a). Finance and Growth: Schumpeter might be right. Quarterly Journal of Economics, 108(3), 717-738.

King, R. G., \& Levine, R. (1993b). Finance, entrepreneurship and growth. Journal of Monetary Economics, 32(3), 513-542.

Kroszner, R. S. (1999). Is the Financial System Politically Independent? Perspectives on the Political Economy of Banking and Financial Regulation. Chicago, IL: University of Chicago.

Lapavitsas, C. (2003). Social Foundations of Markets, Money and Credit. London: Routledge.

Levine, R. (1997). Financial Development and Economic Growth: Views and Agenda. Journal of Economic Literature, 35(2), 688-726.

Mishra, J., Verma, R., \& Singh, V. (2001). Socio-Economic Analysis of Rural Self-Help Groups Scheme in Block Amaniganj, District Faizabad (Uttar Pradesh). Indian Journal of Agricultural Economics, 56(3), 473.

Motwani, A. (2005). Microfinance: Field Observations. Economic \& Political Weekly(July 23).

News Bureau. (2005, May 30). AP to rationalise SHGs interest rate subsidy. Business Line, The Hindu.

NSSO. (2000). Household Consumer Expenditure in India (July-December 1999), Key Results (No. 453 (55/1.0/1)). New Delhi: National Sample Survey Organisation, Ministry of Statistics \& Programme Implementation, Government of India.

NSSO. (2005). Household Indebtedness in India as on 30.06 .2002 (No. 501 (59/18.2/2)). New Delhi: National Sample Survey Organisation, Ministry of Statistics and Programme Implementation, Government of India.

Pandey, P. K., \& Mishra, S. K. (2004). Levels, Differentials and Determinants of Women Empowerment in Uttar Pradesh. In M. Srivastava (Ed.), Economy of Uttar Pradesh: Emerging Challenges (pp. 145-153). Varanasi.

Pedersen, J. D. (2000). Explaining Economic Liberalization in India: State and Society Perspectives. World Development, 28(2), 265-282.

Radhakrishna, R., \& Ray, S. (Eds.). (2005). Handbook of Poverty in India- Perspectives, Policies, and Programmes. New Delhi: Oxford University Press.

RBI. (2003). Annual Report, 2002-03. Mumbai, India: Reserve Bank of India.

RBI. (2004). Basic Statistical Returns Relating to Banking in India. Mumbai: Reserve Bank of India.

RBI. (2005). Report on Trend and Progress of Banking in India 2004-05. Mumbai, India: Reserve Bank of India.

RBI. (2006). Survey of Small Borrowal Accounts, 2004. Reserve Bank of India Bulletin, 60(7), 809-852.

Reddy, Y. (2004). Credit Policy, Systems and Culture. Reserve Bank of India Bulletin, 58(3), 303-311.

Ruthven, O., \& Kumar, S. (2002). Moving Mud, Shifting Soil: Change and Development in Wage Labour Livelihoods in Uttar Pradesh, India (Working Paper No. 176). London: Overseas Development Institute, 111 Westminister Bridge Road, London, UK. 
Schumpeter, J. A. (1934). The Theory of Economic Development: An Inquiry into Profits, Capital, Credit, Interest and the Business Cycle (Translated from the German by Redvers Opie, Trans.). Cambridge, Massachusetts: Harvard University Press.

Shylendra, H. (2006). Microfinance Institutions in Andhra Pradesh, Crisis and Diagnosis. Economic \& Political Weekly( May 20), 1959-1963.

Skaggs, N. T. (1999). Adam Smith on growth and credit :Too weak a connection? Journal of Economic Studies, 26(6), 481-496.

Skaggs, N. T. (2003). H.D.Macleod and the Origins of the Theory of Finance in Economic Development. History of Political Economy, 35(3), 361-384.

Stallings, B., \& Studart, R. (2006). Finance for Development: Latin America in Comparative Perspective. Washington, DC: Brookings Institution Press, United Nations Economic Commission for Latin America and the Caribbean.

Stiglitz, J (2000, June 26). Development Thinking at the Millennium, Paper presented at the Annual World Bank Conference on Development Economics, Paris, France.

UN. (2003). Indicators for Monitoring the Millennium Development Goals: Definitions, Rationale, Concepts and Sources. New York: Department of Economic and Social Affairs, Statistics Division, United Nations.

UPERC.Some Statistics at a Glance. Retrieved January 25, 2007, from www.uperc.org

Varman, M. (2005). Impact of Self Help Groups on Formal Banking Habits. Economic \& Political Weekly(April 23), 1705-1713.

Virmani, A. (2004). India's Economic Growth from Socialist Rate of Growth to Bharatiya Rate of Growth (ICRIER Working Paper No. 122). New Delhi, India: Indian Council for Research on International Economic Relations.

Vyas, V. S. (2004). Report of the Advisory Committee on Flow of Credit to Agriculture. Mumbai, India: Reserve Bank of India.

Yoshino, N., \& Nakahigashi, M. (2000). The Role of Infrastructure in Economic Development (Preliminary Version).Unpublished manuscript. 
Table 1: G-GUIDE of Credit: Variables and Indicators Used

\begin{tabular}{|c|c|c|}
\hline Variable & Questions Raised & Indicators Used \\
\hline Growth & $\begin{array}{c}\text { Has credit served as the source } \\
\text { of overall output growth and } \\
\text { sector growth? }\end{array}$ & $\begin{array}{c}\text { Credit/ Output ratio } \\
\text { Sector credit/ sector output ratio }\end{array}$ \\
\hline Globalisation & $\begin{array}{c}\text { Has credit helped in } \\
\text { globalisation? }\end{array}$ & Credit for infrastructure* \\
\hline Urban transformation & $\begin{array}{c}\text { Is credit leading to increase in } \\
\text { urbanisation? }\end{array}$ & $\begin{array}{c}\text { Credit to urban areas; credit } \\
\text { according to purpose** }\end{array}$ \\
\hline Inequality & $\begin{array}{c}\text { Is credit leading to inequality } \\
\text { between rural and urban areas; } \\
\text { between small and large } \\
\text { borrowers? }\end{array}$ & $\begin{array}{c}\text { Credit to rural areas vis-à-vis } \\
\text { urban areas } \\
\text { Credit to small borrowers vis-à- } \\
\text { vis large borrowers }\end{array}$ \\
\hline Development & $\begin{array}{c}\text { Is credit leading to reduction in } \\
\text { poverty }\end{array}$ & $\begin{array}{c}\text { Credit to small borrowers and } \\
\text { microcredit }\end{array}$ \\
\hline Empowerment & $\begin{array}{c}\text { Has credit helped in the } \\
\text { empowerment of women? }\end{array}$ & \begin{tabular}{c} 
Bank credit to women*** \\
\hline
\end{tabular} \\
\hline
\end{tabular}

* The proxy indicator representative of global integration could be foreign trade and overseas acquisitions. In our study, infrastructure is taken as the closest indicator of globalisation as in the absence of adequate and good infrastructure other activities such as foreign trade etc may not take place.

**: Due to lack of availability of data, this does not consider credit to some large borrowers head offices of which are often located in the urban areas but the utilisation of credit could be in the rural or semiurban areas where their plants may be actually located.

*** Although this indicator does have limitations as access of bank credit to women may be low due to their poor access to collateral assets required in the first place to be eligible for credit, in turn an outcome of the patriarchal nature of the society. Nevertheless, it does highlight lack of empowerment of women and their inability in receiving credit.

Table 2: Credit Inequality in Different States

\begin{tabular}{|c|c|c|c|c|c|c|c|c|c|c|}
\hline \multirow[t]{2}{*}{ States } & \multicolumn{4}{|c|}{$\begin{array}{l}\text { Proportion of rural and urban credit } \\
\text { in total credit }\end{array}$} & \multicolumn{2}{|c|}{$\begin{array}{l}\text { Variation in } \\
\text { credit } \\
(2004 \text { over } \\
1996)\end{array}$} & \multicolumn{2}{|c|}{$\begin{array}{l}\text { Proportion of } \\
\text { rural credit to } \\
\text { urban credit } \\
1996 \quad 2004\end{array}$} & \multirow[t]{2}{*}{$\begin{array}{c}\text { Credit } \\
\text { Inequali } \\
\text { ty } \\
(2004) \\
\end{array}$} & \multirow[t]{2}{*}{$\begin{array}{c}\text { Proportion } \\
\text { of semi- } \\
\text { urban to } \\
\text { urban credit }\end{array}$} \\
\hline & Rural & Urban & Rural & Urban & Rural & Urban & $\mathrm{R} / \mathrm{U}$ & $\mathrm{R} / \mathrm{U}$ & & \\
\hline Madhya Pradesh & 23.4 & 76.6 & 19.9 & 80.1 & -15.2 & 4.6 & 30.6 & 24.8 & -5.8 & 29.4 \\
\hline West Bengal & 13.0 & 87.0 & 9.6 & 90.4 & -26.0 & 3.9 & 14.9 & 10.6 & -4.3 & 6.8 \\
\hline Maharashtra & 5.3 & 94.7 & 3.9 & 96.1 & -26.4 & 1.5 & 5.6 & 4.1 & -1.5 & 4.3 \\
\hline Gujarat & 17.5 & 82.5 & 12.3 & 87.7 & -29.8 & 6.3 & 21.3 & 14.0 & -7.2 & 14.7 \\
\hline Andhra Pradesh & 21.2 & 78.8 & 21.8 & 78.2 & 2.9 & -0.8 & 26.9 & 27.9 & 1.0 & 22.6 \\
\hline Karnataka & 16.3 & 83.7 & 19.4 & 80.6 & 18.8 & -3.7 & 19.5 & 24.0 & 4.5 & 16.0 \\
\hline Kerala & 8.1 & 91.9 & 6.3 & 93.7 & -22.4 & 2.0 & 8.8 & 6.7 & -2.1 & 56.0 \\
\hline Tamilnadu & 13.1 & 86.9 & 9.4 & 90.6 & -28.8 & 4.3 & 15.1 & 10.3 & -4.8 & 15.1 \\
\hline Haryana & 31.1 & 68.9 & 22.1 & 77.9 & -29.1 & 13.2 & 45.2 & 28.3 & -16.9 & 32.5 \\
\hline Punjab & 29.8 & 70.2 & 25.9 & 74.1 & -13.3 & 5.6 & 42.5 & 34.9 & -7.6 & 31.5 \\
\hline Rajasthan & 26.7 & 73.3 & 20.4 & 79.6 & -23.7 & 8.6 & 36.4 & 25.6 & -10.8 & 22.8 \\
\hline Bihar & 46.2 & 53.8 & 39.5 & 60.5 & -14.7 & 12.6 & 86.0 & 65.2 & -20.8 & 43.0 \\
\hline Orissa & 32.5 & 67.5 & 35.0 & 65.0 & 7.7 & -3.7 & 48.2 & 53.9 & 5.7 & 39.8 \\
\hline UP & 29.5 & 70.5 & 26.8 & 73.2 & -9.1 & 3.8 & 41.8 & 36.7 & -5.2 & 24.8 \\
\hline
\end{tabular}

Source: Complied from RBI (2004, various issues). 

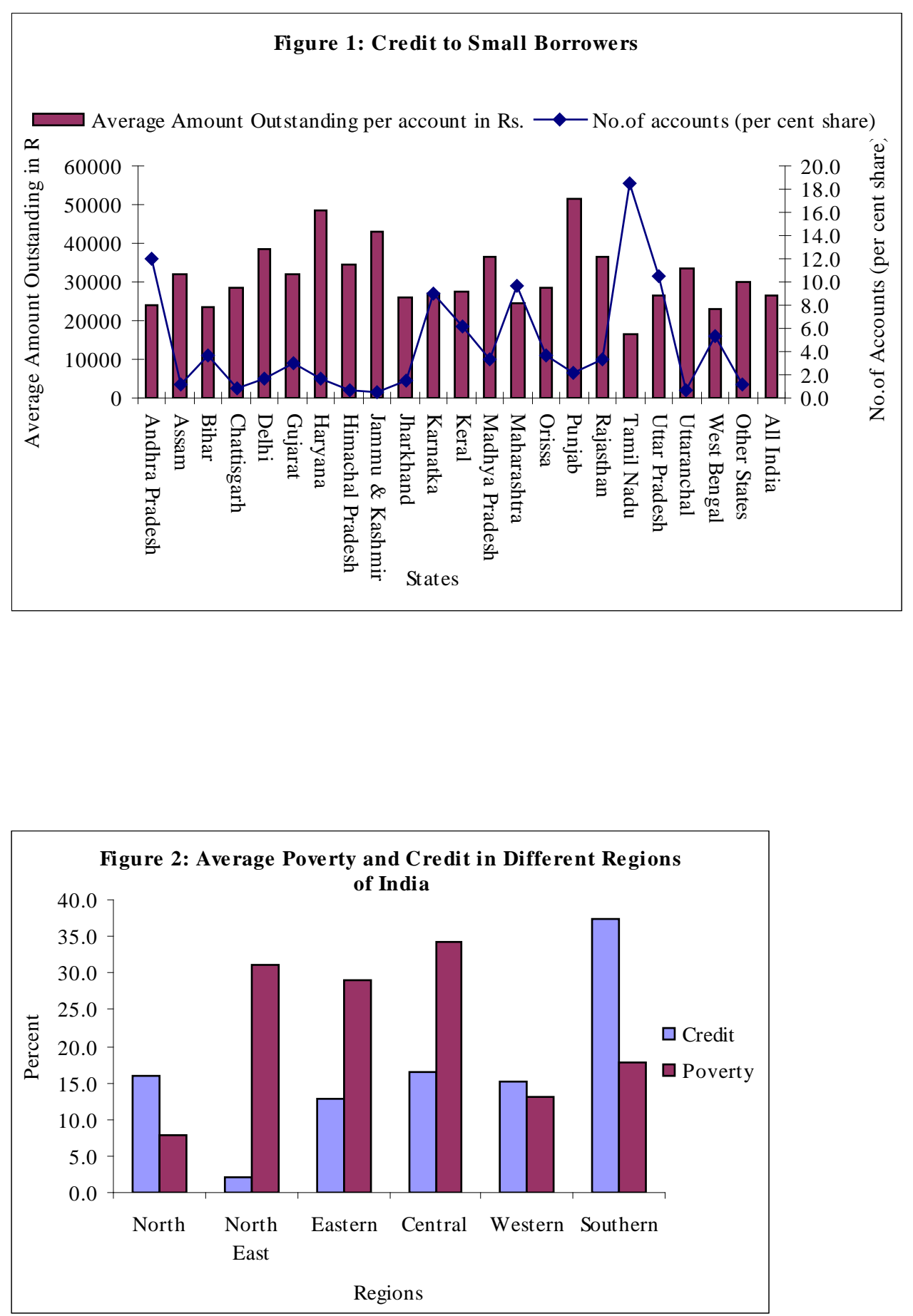